\title{
DESCRIPTIONS AND RECORDS OF NEOTROPICAL CONOPIDAE (DIPTERA)
}

\author{
By SIDNEY CAMRAS \\ Chicago, Illinois
}

The first part of this paper may be considered an addendum to my work on New World Conops and allies (1955, Proc. U.S. Nat. Mus., 105, 155-187). A number of other apparently new forms have been seen; but I am awaiting more material, or the opportunity for a revisional study in the case of Zodion.

Diconops, subgen. nov.

Belonging to the genus Conops, but having a relatively long and narrow second abdominal segment. Second abdominal segment (female) dorsally, about three times as long as wide, sides parallel. Third segment about threefourths as long as second, apex nearly two times as wide as base. One propleural bristle on the type species, none on the other species. Posterior margin of eye more concave than usual. Polished triangular area at posterior margin of eye nearly absent.

Type: Conops trichus, sp. nov.

This subgenus could be placed in Physoconops, as a group lacking the ocellar tubercle; but I consider the absence of the ocellar tubercle more characteristic of the genus Conops than the wide abdomen.

The male is as yet unknown.

Conops (Diconops) trichus, sp. nov.

Holotype $q$ : Brazil: Nova Teutonia, Santa Catarina, Nov. 1952, F. Plaumann (author's collection).

Vertex yellow, rounded anteriorly, black laterally. Front yellow with black "T" pattern. Face and upper grooves yellow. Lower face and grooves, and cheeks black. Facial grooves and orbital yellow pollinose. Occiput black. Anten- 
na mainly black. Reddish yellow on third segment medially and on the first segment. First antennal segment four times as long as wide. Second segment nearly twice as long as first. Third segment about three-fourths as long as second. Arista three segmented, without lateral process on the second segment. Proboscis nearly twice as long as head; black, with yellow on apical ventral half.

Thorax black. Gold pollinose faintly on dorsum, with distinct areas medial to the humeri, at base of wings, and at the scutellum. Pleura with distinct yellow pollinose stripe. Legs brownish yellow, partly black on coxae, apical tarsal segments, and most of claws. Wings yellowish hyaline, with brownish yellow pattern between first vein and third vein and vena spuria. Yellow in costal, subcostal, and first basal cells. Calypters and halteres brownish yellow.

Abdomen black, yellow at fused junction of second and third segments. Apical margin of third segment, fourth, fifth, and sixth segments yellow pollinose, more distinct at distal margin. The hairs on the third to sixth segments more distinct than usual. Theca and genital segments shining black. Subapical genital segment mainly reddish. Theca as long as wide, and relatively thin.

Size: $14 \frac{1}{2} \mathrm{~mm}$. (without antenna).

Paratype o : same data, Dec. 1952.

Similar to the holotype. Posterior femora darker at basal half. Theca yellowish anteriorly.

Size: $151 / 2 \mathrm{~mm}$.

This species keys to Physoconops gracilior (Camras, 1955, Proc. U. S. N. M., 105:186) but differs in the color of the vertex, facial grooves, cheeks, etc., in addition to the generic difference.

Conops (Diconops) geminatus, sp. nov.

Holotype $q$ : Peru: Monson Valley, Tingo Maria, Dec. 11, 1954, E. I. Schlinger and E. S. Ross (California Academy of Sciences, San Francisco).

Vertex yellow, black on each side forming a velvety black triangular mark on each side of the front with the black " $T$ " pattern of the front. Remainder of front, face, 
and upper facial grooves yellow. Cheeks and remainder of facial grooves black. Facial grooves, orbitals and interrupted post-vertical stripe gold pollinose. Occiput black. Antenna black. First antennal segment four times as long as wide. Second segment nearly two times as long as first. Third segment one and one-half times length of first. Arista three segmented. Lateral process on second segment indistinct. Proboscis two times length of head, black with yellow on about distal ventral half.

Thorax black, with considerable gold pollen on dorsum covering it completely in certain views. In other views, there are three black stripes on the dorsum. A distinct gold pollinose pleural stripe is connected with the gold pollen of the dorsum. Legs yellow; blackish partly on coxae, base of hind femora, tarsi, except base of first tarsus, and claws. Wings hyaline, brownish pattern between costa, and third vein and vena spura. The dark pattern in the first posterior cell is confined to less than the anterior half. Calypters dark yellow. Halteres bright lemon yellow, brown at base of stem.

Abdomen black, yellowish at junction of second and third segments. Gold pollinose at junction of first and second, second and third, and distal margins of remaining segments. Fifth, sixth, and base of seventh segments gold pollinose. Genital segments and theca dark reddish yellow. Theca as long as wide.

Size: $81 / 2 \mathrm{~mm}$. (without antenna).

This species is similar to trichus but differs mainly in the color of the front, thorax, and wings. Although very different in appearance, they are probably geographical representatives. This species keys to Physoconops antennatus (Camras, 1955, Proc. U. S. N. M. 105:186) but differs in generic and color characters.

\section{Physoconops parsonsi Camras}

1955, Proc. U. S. Nat. Mus., 105, 171.

The types of this species had been erroneously placed in the U.S. National Museum Collection. P. J. Darlington, Jr., called our attention to this, and the types have been returned to the Museum of Comparative Zoology. 


\section{Physoconops pictus (Fabricius)}

In the above mentioned paper ( $p .166$ ), the specimens from Havana, Cuba, and Manneville, Haiti, recorded from the U.S. National Museum, likewise belonged to the Museum of Comparative Zoology, and have been returned to that collection.

\section{Physoconops (Shannonoconops) apicalis Camras}

1955, Proc. U.S. Nat. Mus. 105, 172.

This distinctive form was described from a male from Mato Grosso, Brazil, and a female from Peru. Since then, I have received a male and a female from Nova Teutonia, Santa Catarina, Brazil, collected by F. Plaumann.

\section{Physoconops analis (Fabricius)}

This name replaces Physoconops angustifrons (Williston) in my review (1955, Proc. U.S. Nat. Mus. 105, 178).

This important change of names has been made in my paper on New World Physocephala (1957, Ann. Ent. Soc. Am. 50, 217), but is repeated here as it is apt to be overlooked.

Zodion rossi, sp. nov.

Holotype $\delta$ : Mexico: San Luis Potosi ; 40-50 miles N. W. C. del Maiz, Nov. 20, 1948, E. S. Ross (California Academy of Sciences, San Francisco).

Head pale yellow. Sides of upper front and vertex dark reddish. Center of ocellar tubercle black. Upper occiput blackish, lower occiput yellow. Antenna deep yellow, somewhat orange on third segment. First segment very short, shorter than wide. Third segment slightly longer than second. Arista black. Proboscis one and one-half times length of head; black, brownish at base. Palpi slightly longer than width of proboscis at base.

Thorax yellow. Dorsum black with grayish yellow pollinose submedian and sublateral lines. These lines joining posteriorly. The sublateral line is interrupted in the middle by the transverse suture. Humeri, light yellow. Scutellum deeper yellow, with a large tuft of black hairs on each side. Apical margin of scutellum slightly concave. 
Pleura mainly yellow. Sternopleura mainly black. Legs mainly yellow, dark reddish distally and dorsally on the femora. Tibiae more yellowish in the middle. Apical tarsi and apical half of claws black. Wings hyaline, yellow at base. First posterior cell long petiolate. Calypters light yellow. Halteres light yellow, dark reddish at base.

Abdomen mainly deep yellow with paler yellow distal margins. Blackish red on first, basal two-thirds of second, about basal one-half of third, and basal centers of fourth and fifth segments. Sides of second and third segments yellow. Genital segments darker yellow.

Size: $5 \mathrm{~mm}$.

Allotype $\%$ : Same data.

Similiar to the holotype. Dorsal third of front and vertex rufous. Abdomen more predominantly dark rufous on most of the segments dorsally, yellow laterally and on distal margins. Median longitudinal yellow band on fifth, sixth and seventh segments. Genital segments black. Theca apparently as long as wide. Size: $51 / 2 \mathrm{~mm}$.

Paratype $\delta$ : Same data. (Retained in author's collection).

Similiar to the holotype, but somewhat more rufous on vertex and abdomen. Size: $41 / 2 \mathrm{~mm}$.

This very distinctive form differs structurally from the other species of Zodion in the scutellum and wing venation, and could be placed in a separate subgenus.

Scatoccemyia, gen. nov.

Similar to Occemyia but having a markedly thickened anterior cross vein, shorter, thicker antenna, more quadrate shaped head, a fronto-facial black mark, more prominant rows of bristles on ventral surface of femora, more pollinose (less shiny black) coloration, and more hairy appearance.

Type: Scatoccemyia plaumanni, sp. nov.

This genus resembles a Scatophagid. Since the genus Occemyia has not been found in South America as yet, this genus may be replacing it on that continent. 


\section{Scatoccemyia plaumanni sp. nov.}

Holotype $\hat{0}:$ Brazil; Santa Catarina; Nova Teutonia, September 1955, F. Plaumann (author's collection).

Vertex black, darker laterally and on ocellar tubercle. Three distinct ocelli. Front rufous, darker near vertex. Face, facial grooves, and cheeks yellow, rufous in some areas, blackish in center of grooves. A black mark at the fronto-facial junction which is lower than antennal base, more than usual, due to antennal base being higher than usual. This gives the more quadrate shaped head when viewed from the side. A black line along oral margin. Cheeks more than half of eye-height. Occiput blackish above, dark yellow below, yellowish gray pollinose. Antenna, including arista, black. Medial surface of second antennal segment dark reddish. Basal half of third antennal segment bright rufous. First antennal segment as long as wide. Second segment two times length of first. Third segment two times length of second. Proboscis black, geniculate at middle. Middle segment two times length of head.

Thorax black, brownish pollinose. Dorsum with indistinct dark lines. Legs mainly black, basal half to threefifths yellow. Anterior surface of anterior femur dark yellowish. Ventral apical margin of anterior and middle femora dark yellow. Tibiae partly yellowish, especially at base and center of posterior tibia. Tarsi partly yellowish. Apical tarsal segment and apical half of claws black. Wings hyaline, faintly brownish along the veins. Stigma at apex of first and second veins yellowish. Anterior crossvein markedly thickened in the middle. First posterior cell widely opened. Opening slightly longer than anterior cross vein. Calypters pale yellow. Halteres yellow, dark reddish at base of stem.

Abdomen black, yellowish gray pollinose more distinct laterally and along distal margin of each segment. Distal margin of fourth and fifth segments and most of sixth segment dark reddish. Genitalia mainly black.

Size: $5 \frac{1}{2} \mathrm{~mm}$. (without antenna). 
Stylogaster lopesi, sp. nov.

Holotype $q$ : Brazil: Santa Catarina; Nova Teutonia, Dec. 7, 1949, F. Plaumann (author's collection).

Ocellar triangle shining black, nearly equilateral, and nearly touching the frontal lunule. Front velvety black. Orbitals, face, and cheeks yellowish white pollinose. Facial keel with narrow black line. Occiput black above, gray pollinose laterally and below. Antenna dark yellowish, brighter on inner ventral surface of third segment. Arista black. First antennal segment as long as wide; second segment four times as long as first; third segment as long as second, gradually narrowing apically. Proboscis black, yellowish on apical third of distal segment. Apical segment about three times length of head.

Thorax black, yellowish on humeri and pleura at base of wing. Dark yellowish at posterior calli. Anterior and middle coxae yellowish black, posterior coxa deep black. Trochanters mostly black. Anterior and middle legs yellow except blackish at base of femora, apical tarsi, and claws. Posterior femur black with narrow yellow band just proximal to the middle. Posterior tibiae black with distinct white preapical band, which is entirely white haired. Posterior tarsi and claws black. Wings dusky hyaline, slightly brownish anteriorly. First posterior cell widest at distal third and wider than submarginal cell. Calypters whitish yellow. Halteres yellowish, reddish at apex and base of stem, the club blackish.

Abdomen black, yellowish in two spots at base of first segment and triangular basal sides of remaining segments. These pale areas are largest on third and fourth segments. Hairs on sides of first segment white. Those on second segment mostly white but with some black bristles. Ovipositor mainly black, reddish on narrow first segment, narrow base of second segment, and narrow base of third segment. Third segment white on distal three-fifths, reddish yellow at apex with black genital structures. Ovipositor black haired except for proximal one-half to twothirds of white area on apical segment.

Size: $16 \mathrm{~mm}$. (without antenna). Ovipositor $7 \mathrm{~mm}$. 
Allotype $\hat{o}$ : Brazil: Nova Teutonia, Oct. 1952, F. Plaumann (author's collection).

Similar to holotype. Sixth and seventh abdominal segments black. Genitalia yellow. Two patches of yellow hairs on dorsum of seventh segment. No black bristles on sides of second segment. Size: $10 \mathrm{~mm}$.

Paratype $q$ : Brazil: Nova Teutonia, Nov. 9, 1951, F. Plaumann (Natural History Museum, Basle, Switzerland). Similar to holotype. Dark areas somewhat more extensive. Size: $15 \mathrm{~mm}$. Ovipositor $7 \mathrm{~mm}$.

Paratype of: Brazil: Nova Teutonia, Oct. 1954, F. Plaumann (author's collection).

Similar to the allotype. Size $11 \mathrm{~mm}$.

Paratype ô: Brazil: Nova Teutonia, Nov. 1950, F. Plaumann (author's collection).

Similar to the allotype. Size $101 / 2 \mathrm{~mm}$.

This species keys to Curran's couplet 7 , differing from the alternatives in the female by having the apical segment of the ovipositor black haired proximally and apically, and white haired on about the middle third. In the male, this species differs from the alternatives at couplet 7 , by having the basal three-fifths of the posterior tibia entirely black.

Named after H. de Souza Lopes in recognition of his fine work on this genus. 

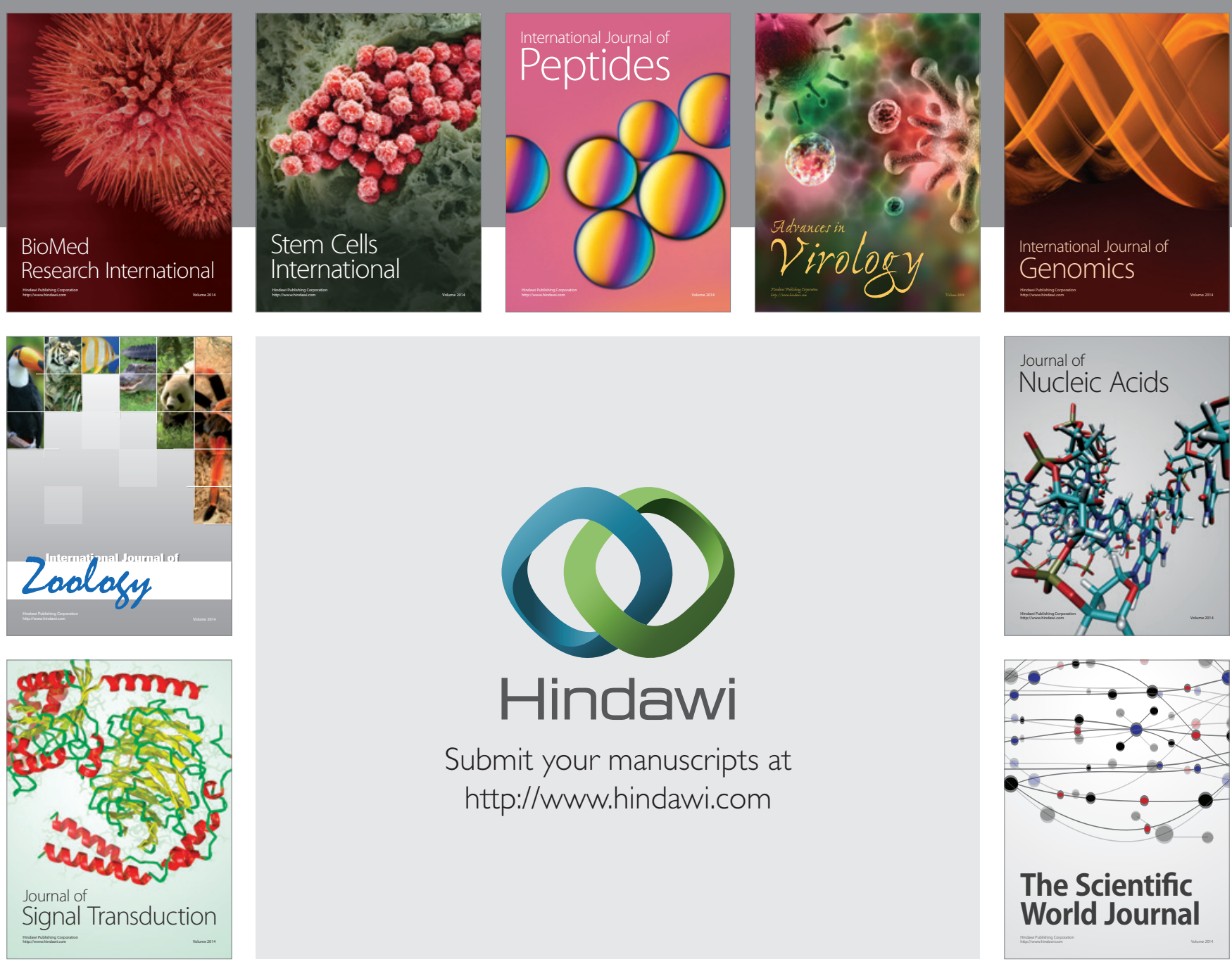

Submit your manuscripts at

http://www.hindawi.com
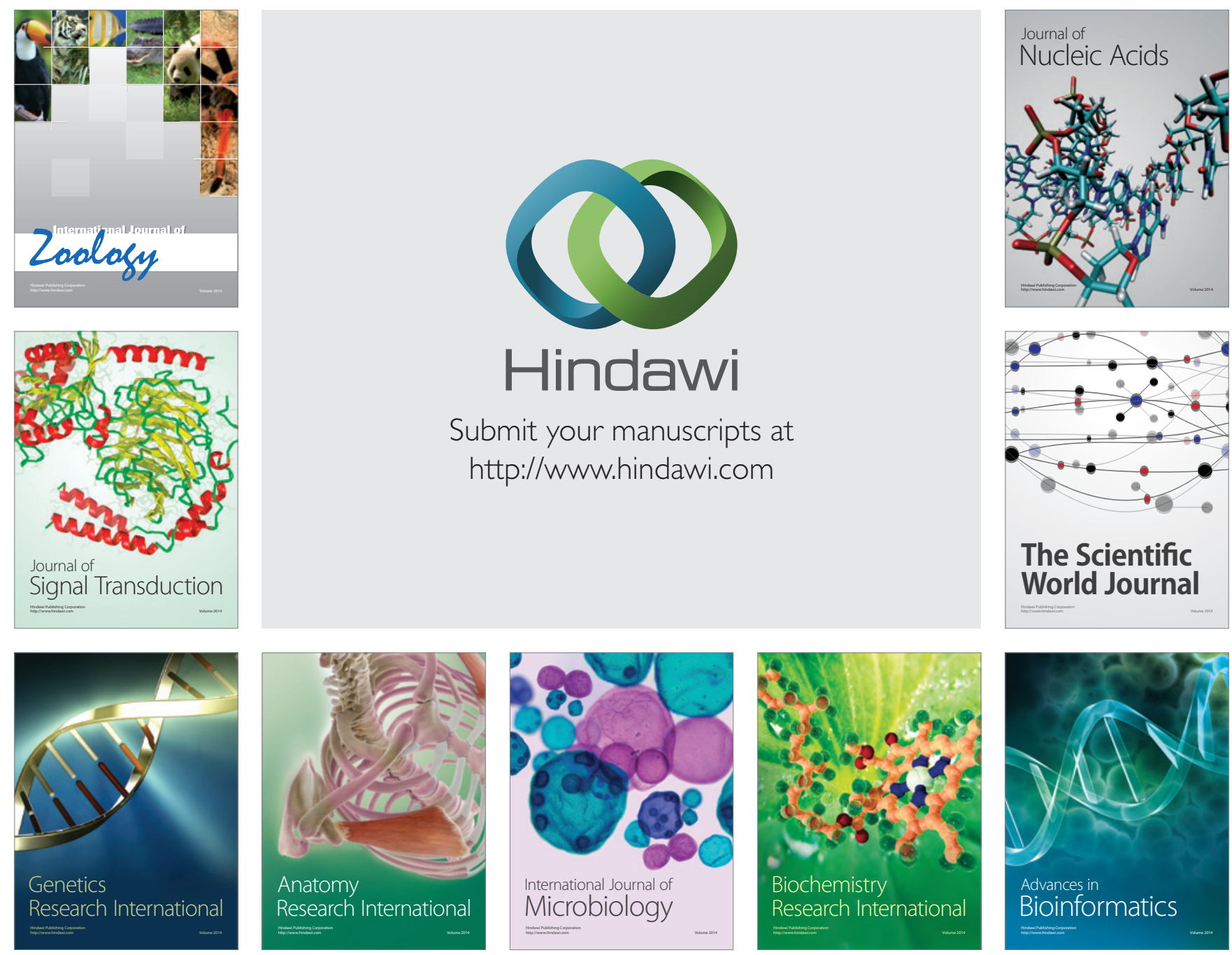

The Scientific World Journal
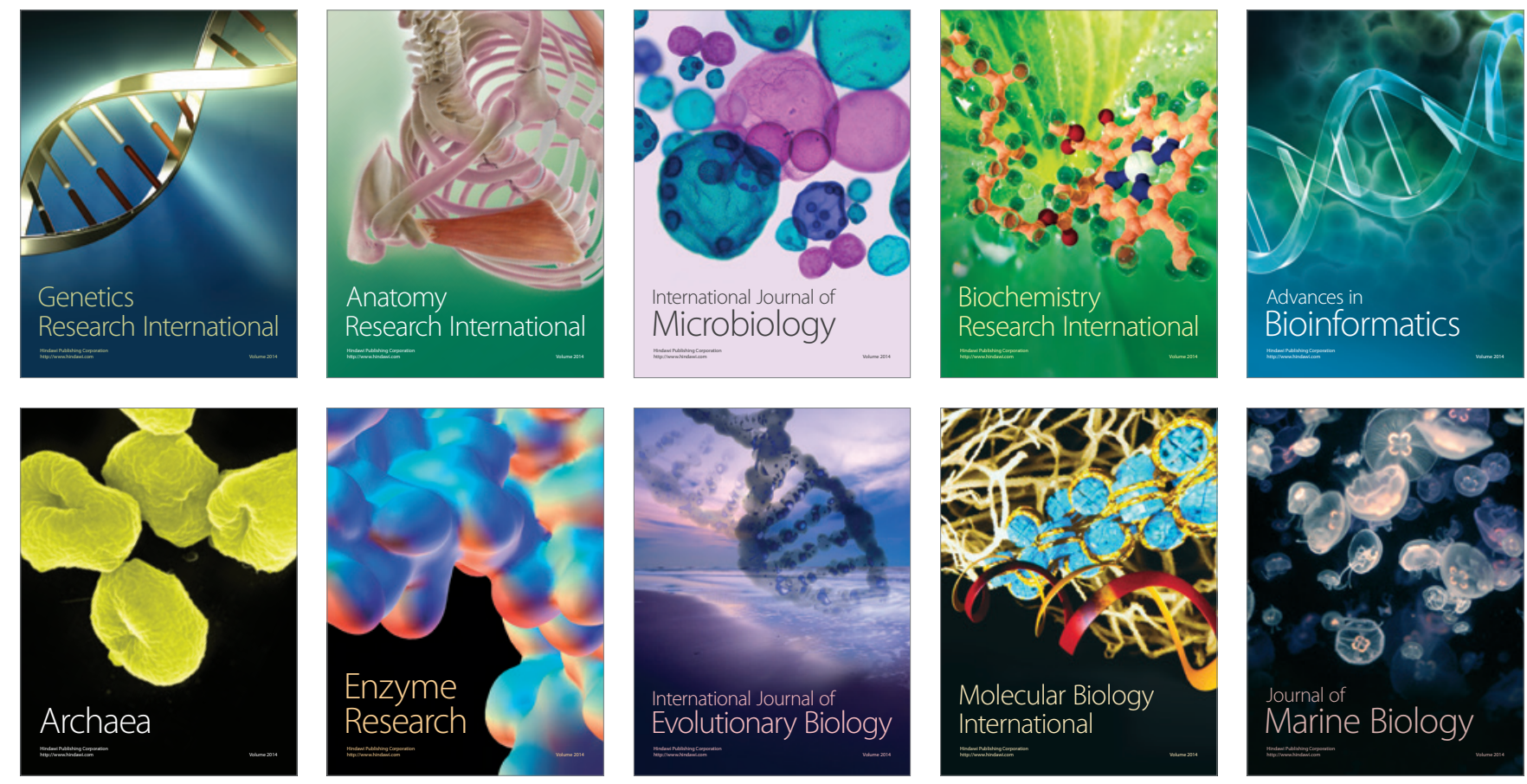